بررسى تحمل به شورى در رقمهاى آلوتترايلوئيد ينبه (Gossypium sp.) به كمك روشهاى

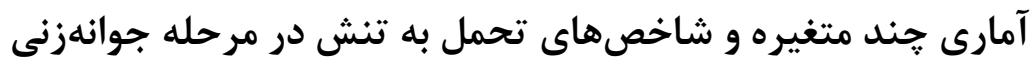

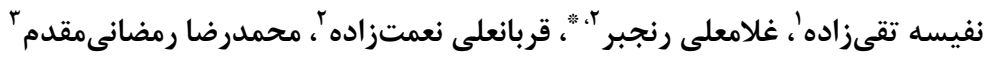

$$
\begin{aligned}
& \text { ' دانشجوى دكترى دانشخاه علوم كشاورزى و منابع طبيعى سارى 'دارى }
\end{aligned}
$$

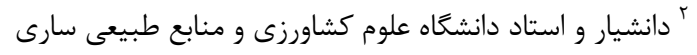

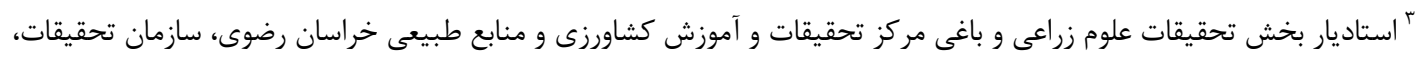

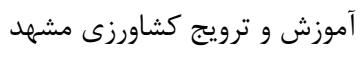

ali.ranjbar@gmail.com بـ"

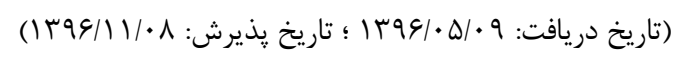

جكيده

شورى يكى از مههمترين عوامل محدودكننده كشاورزى است. هنبه بهعنوان يكى تياه روغنى -اليافى از جمله

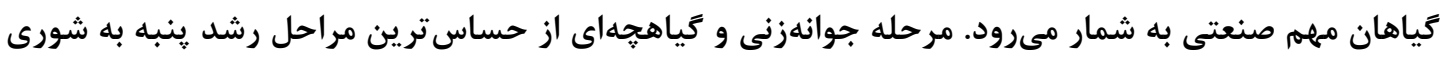

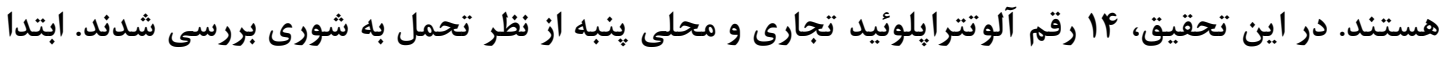

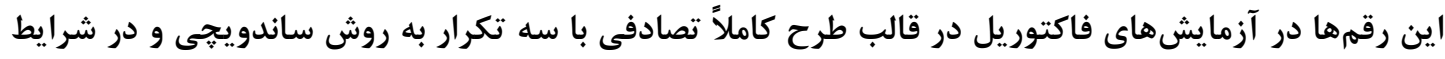

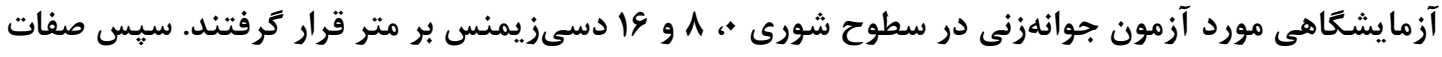

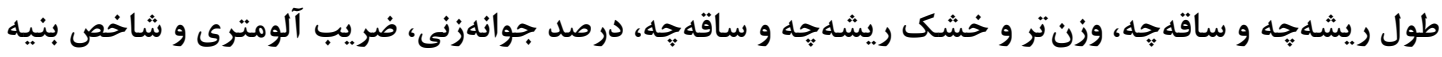

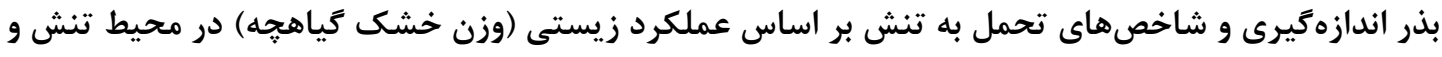

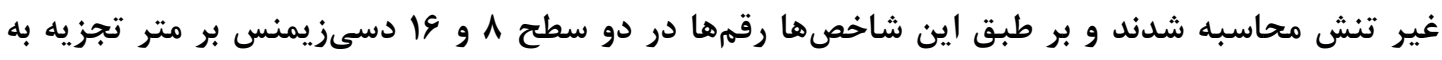

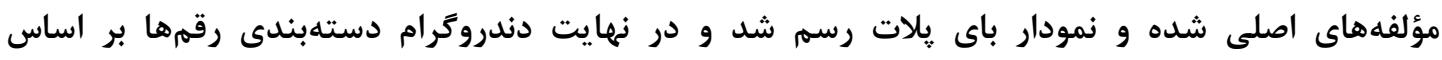

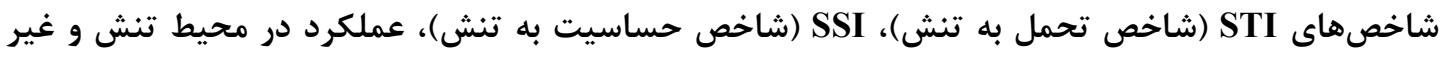

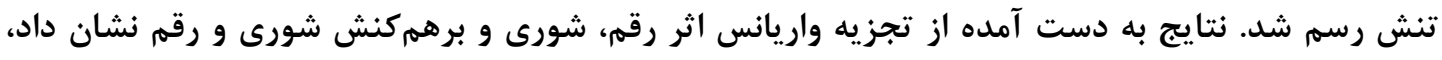

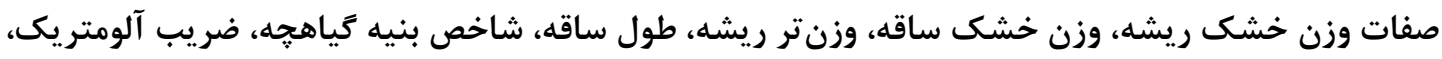

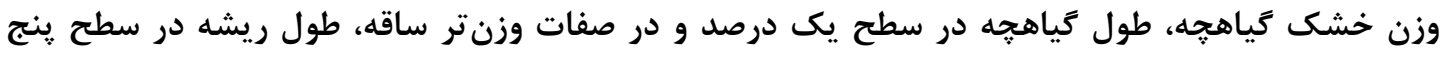

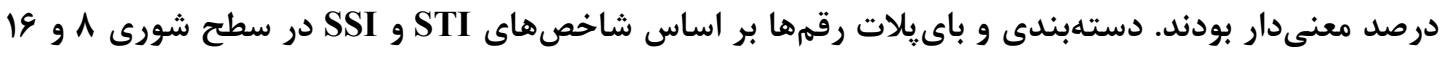

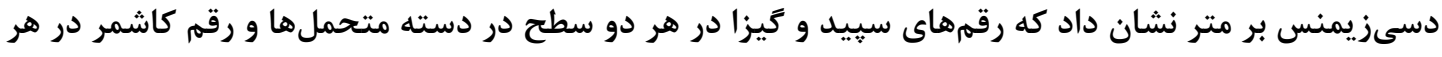

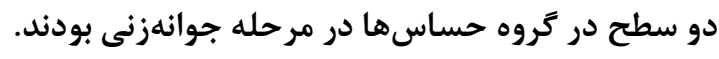
وازههاى كليدى: باى يلات، ينبه، جوانهزنى، شورى، تجزيه مؤلفه اصلى

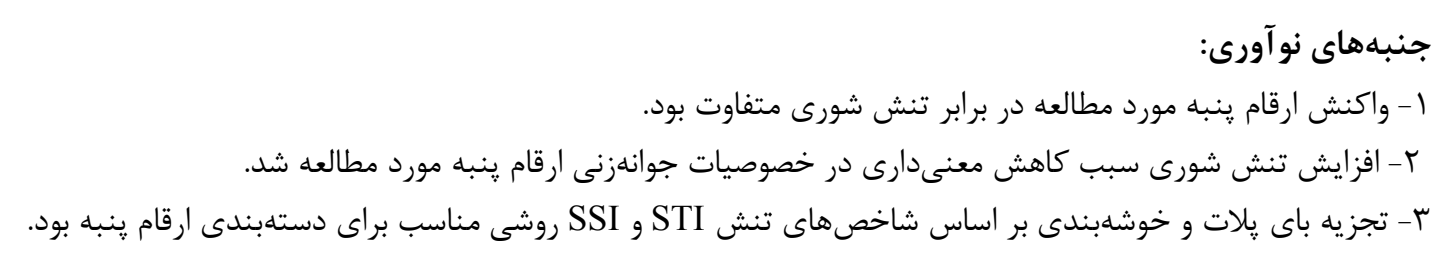

DOI: $10.29252 /$ yujs.4.2.93 


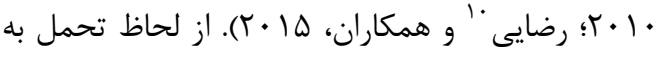

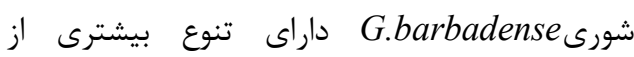
G.arboreum , G.hirsutum كياهجهاى در مقايسه با جوانهزنى داراى حساسيت

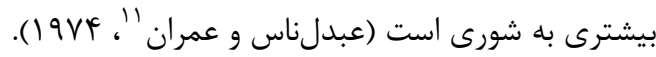
روشهاى مختلفى براى ارزيابى كياهان زراعى نسبت

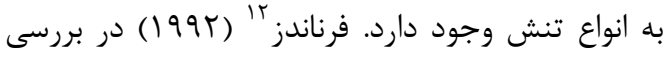
عملكرد رقمها در دو محيط (تنش و شرايط عادى)

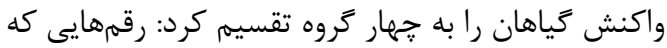

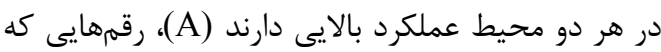

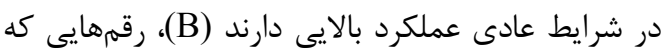
در شرايط تنش عملكرد خوبى دارند (C) و رقمهايى كه در هر دو محيط داراى عملكرد بايينى هستند (D)

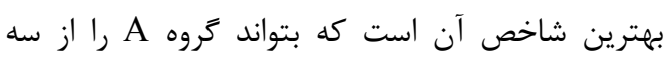

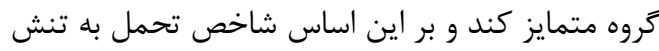

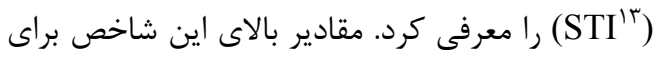

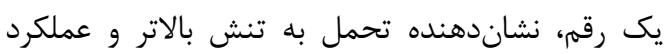

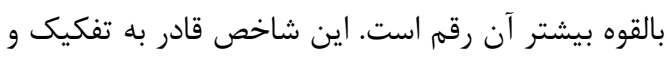
جداسازى كروه A از كروههاى B و C است است. بعلاوه در بين شاخصهاى تحمل برو به تنش، ميزان

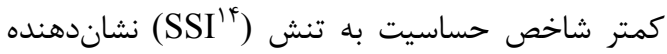
تغييرات كم عملكرد رقم در شرايط تنش نسبت به

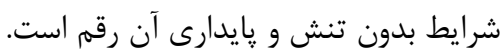

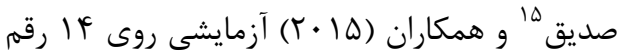
ينبه در مزرعه در منطقه بيرجند در شرايط تنش

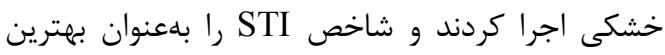
شاخص در هر دو دسته تنش و غير تنش معرفى كردند.

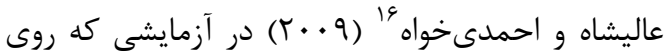

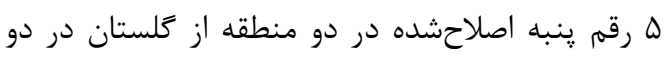

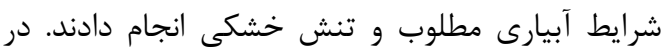
اين تحقيق نيز STI شاخص مناسبى در دستهبندى و

\footnotetext{
${ }^{9}$ Basal

${ }^{10}$ Razaee

${ }^{11}$ Abul-Naas and Omran

${ }^{12}$ Fernandez

${ }^{13}$ Stress Tolerance index

${ }^{14}$ Stress susceptibility index

${ }^{15}$ Sedigh

${ }^{16}$ Alishah and Ahmadikhah
}

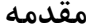
طبق برآوردهاى انجام شده، حسـدود • r درصد از زمينهاى كشاورزى جهان تحت تنش شورى بوده و هرساله نيز به اين آمار افزوده مىشود، علاوه بر اين

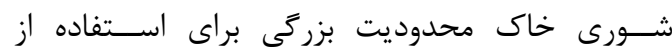

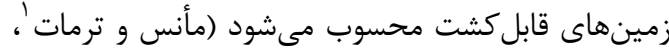
919 (1). محصولات زراعى بلهشدت تحت تأثير تنش شورى قرار مى گيرند، به همين دليل مطالعات بسيارى

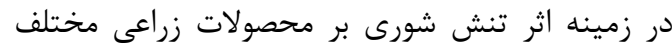
انجام شده است. شورى اثر كاهنده بر خصوصيات مختلف جوانهزنى و رويشى كياهانى همجون سويا (كامروا' و و همكاران،

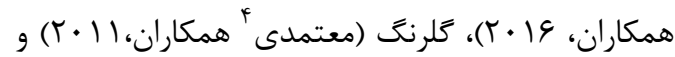

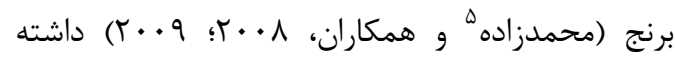

ينبه مهمترين زياه ليفى طبيعى و صنعتى

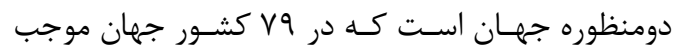

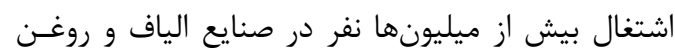
گرديـده و در ميـان دانسههـاى روغنى جهان بعد از

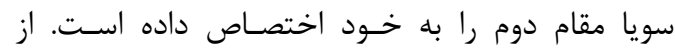
لحاظ تحمل به شورى، ينبه آيلند Gossypium)

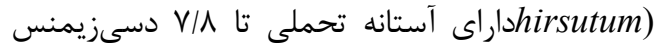

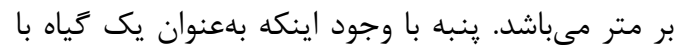
تحمل نسبى به شورى گزارش شده، اما در مئ ميان واريتهها و رقمهاى مختلف آن دامنه متنوعى از تحمل

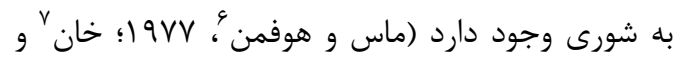

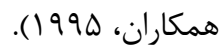
مطالعات زيادى روى تحمل به تنش در زياه ينبه انجام شده كه در تمامى اين تحقيقات كاهش خصوصيات جوانهزنى از جمله سرعت جوانهزنى، وزنتر و

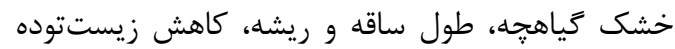

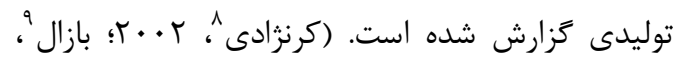

\footnotetext{
${ }^{1}$ Munns and Termaat

${ }^{2}$ Kamrava

${ }^{3}$ Shirazi

${ }^{4}$ Motamedi

${ }^{5}$ Mohammadzadeh

${ }^{6}$ Maas and Hoffmann

${ }^{7}$ Khan

${ }^{8}$ Kor Nejadi
} 
كشت شد. سيس يك حوله كاغذى آغشته به همان محلول كلريد سديم با همان ابعاد و همان غلظت روى بذرها قرار داده شد. حولههاى كاغذى محتوى بذرهاى

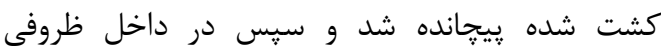
محتوى همان محلول با همان غلظت بلهصورت عمودى قرار داده شدند و ساندويجهاى تهيه شده با احتياط در دران

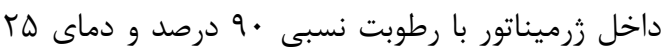
درجه سانتى

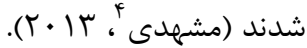
وزنتر و خشك گياهجهها، وزنتر و خشك ريشهجه

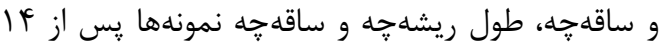
روز اندازهيرى شدند. سيس شاخصهاى تحمل به تنش بر اساس روابط جدول Y و درصد جوانهزنى (رابطه ()، شاخص بنيه كياهجه (رابطه Y)، ضريب آلومتريك (رابطه

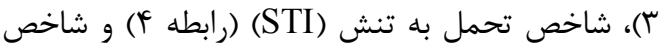
حساسيت به تنش (SSI) (رابطه ه) محاسبه شد.

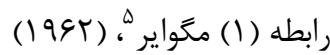

$\mathrm{GP}=(\mathrm{n} / \mathrm{N}) \times 100$

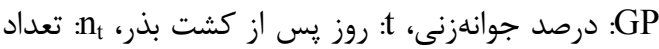
بذر جوانهزده در روز t، N: تعداد كل بذرها $\mathrm{VI}=\mathrm{GP} \times \mathrm{PL}$

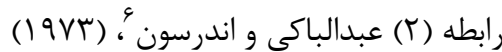
VI : شاخص بنيه بذر، GP: درصد جوانهزنى، PL: طول كياهجه

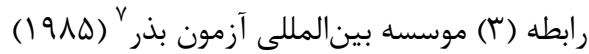

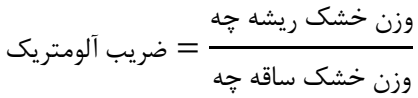

$\mathrm{SSI}=\left(1-\left(\mathrm{Y}_{\mathrm{S}} / \mathrm{Y}_{\mathrm{N}}\right)\right) / \mathrm{SI}$

$\mathrm{SI}=1-\left(\overline{\mathrm{Y}}_{\mathrm{S}} / \overline{\mathrm{Y}}_{\mathrm{N}}\right)$

STI $=\left(\mathrm{Y}_{\mathrm{N}} \times \mathrm{Y}_{\mathrm{S}}\right) /\left(\overline{\mathrm{Y}}_{\mathrm{N}}\right)^{2}$ رابطه (ه) فرناندز، (199T) ميانك ميانگين عملكرد كليه رقمها در محيط بدون تنشئ Ys

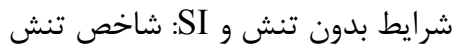

\footnotetext{
${ }^{4}$ Mashhadi

${ }^{5}$ Maguire

${ }^{6}$ Abdul-Baki and Anderson

${ }^{7}$ International Seed Testing Assocociation

${ }^{8}$ Fischer and Maurer
}

جداسازى ارقام متحمل از حساس قلمداد كردند. زنگَى'

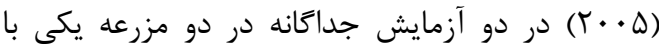

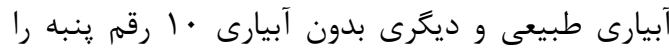

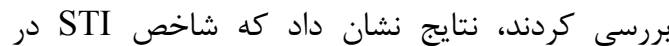
دستهبندى ارقام ينبه شاخصى خوب و مناسب است. در آزمايشهاى مختلف از فاكتورهاى مورفولوزيكى و

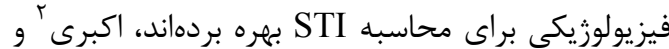

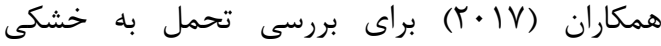
كالوسهاى كندم از شاخص تحمل به خشكى استفاده

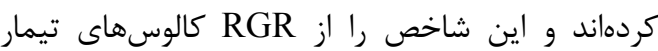

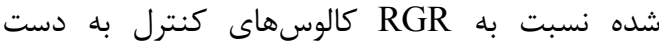

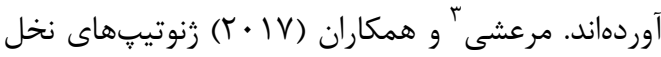
نخل را براى تنش شورى از طريق خصوصيات فيزيولوزيكى كشت بافت بررسى كردند. ايشان براى تمامى اين خصوصيات شاخص STI را محاسبه كردند و

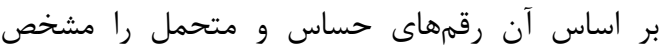

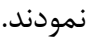
هدف از تحقيق حاضر بررسى تحمل به تنش شورى

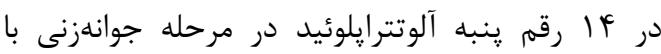
روشهاى آمارى بيشرفته و شاخصهاى تحمل رايج جهت تعيين رقمهاى متحمل و حساس است.

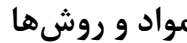

رقمهاى مورد برسى توسط مركز تحقيقات كشاورزى و منابع طبيعى خراسان رضوى تأمين شد كه مشخصات اين رقمها در جدول آدآيده است. اين تحقيق در يزوهشكده زنتيك و زيستفناورى طبرستان انجام شد. بهمنظور بررسى تحمل به شورى رقمهاى ينبه مورد مطالعه آزمايش فاكتوريلى (دو فاكتور شورى و رقم) در

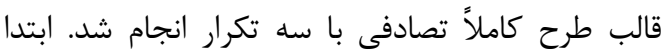
حولهاى از كاغذ صافى در داخل محلولهاى كلريد سديم

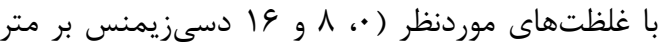
از نمك كلريد سديم) غوطهور شد و پِّ از خاز خارج شدن

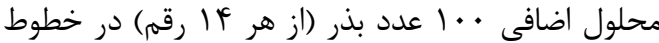
طولى با فواصل معين با فاصله له سانتىمتر از لبه بالايى آلى درافي

\footnotetext{
${ }^{1}$ Zangi

${ }^{2}$ Akbari

${ }^{3}$ Marashi
} 


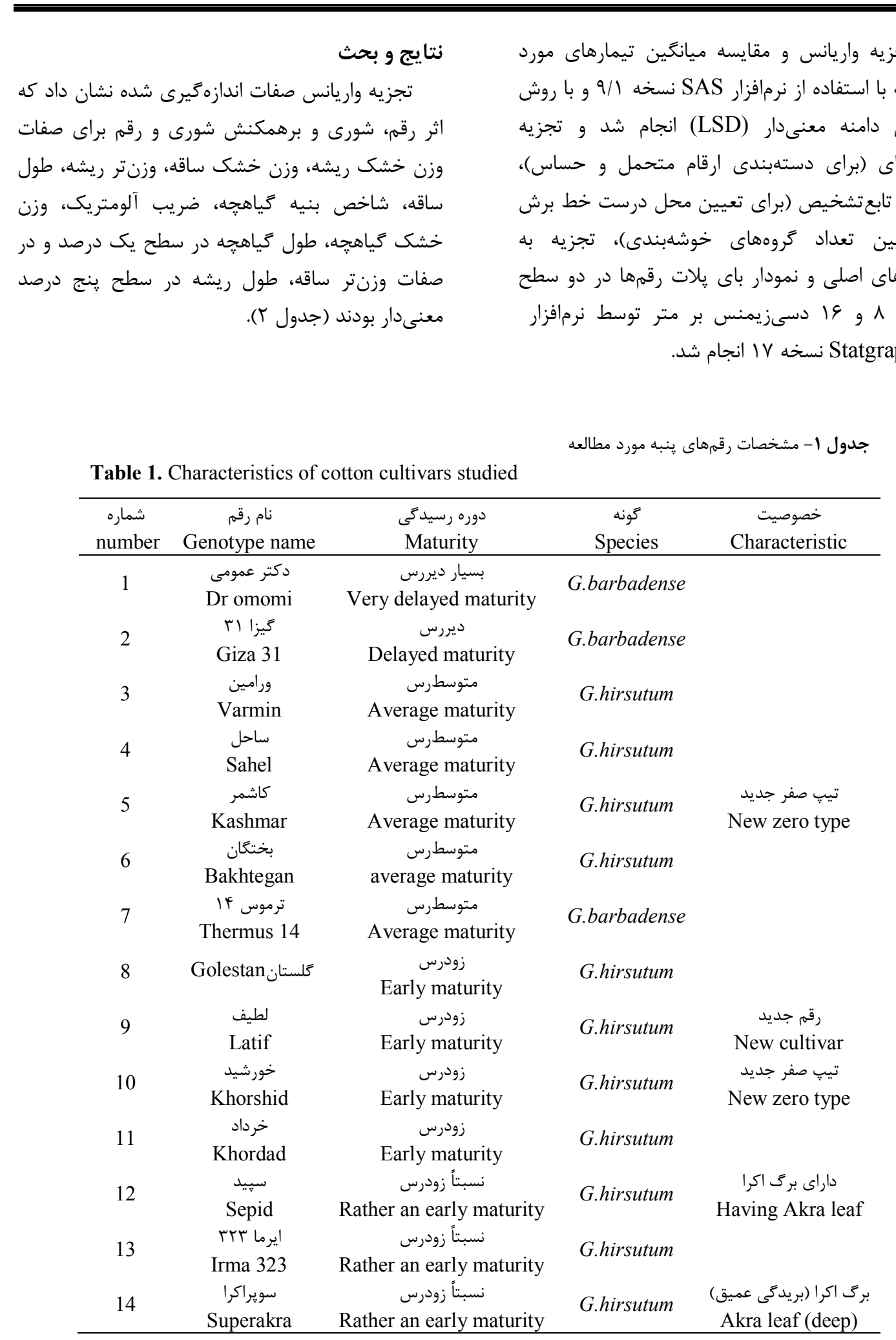




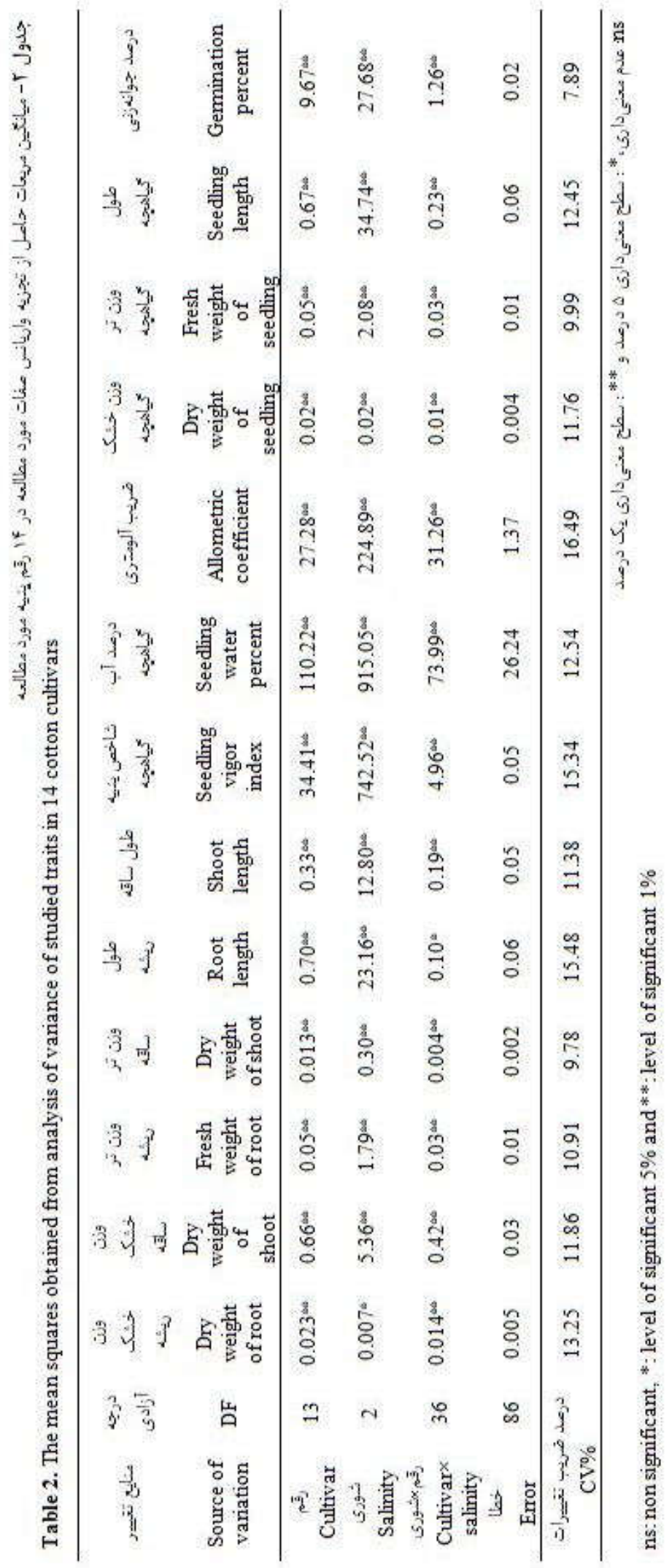




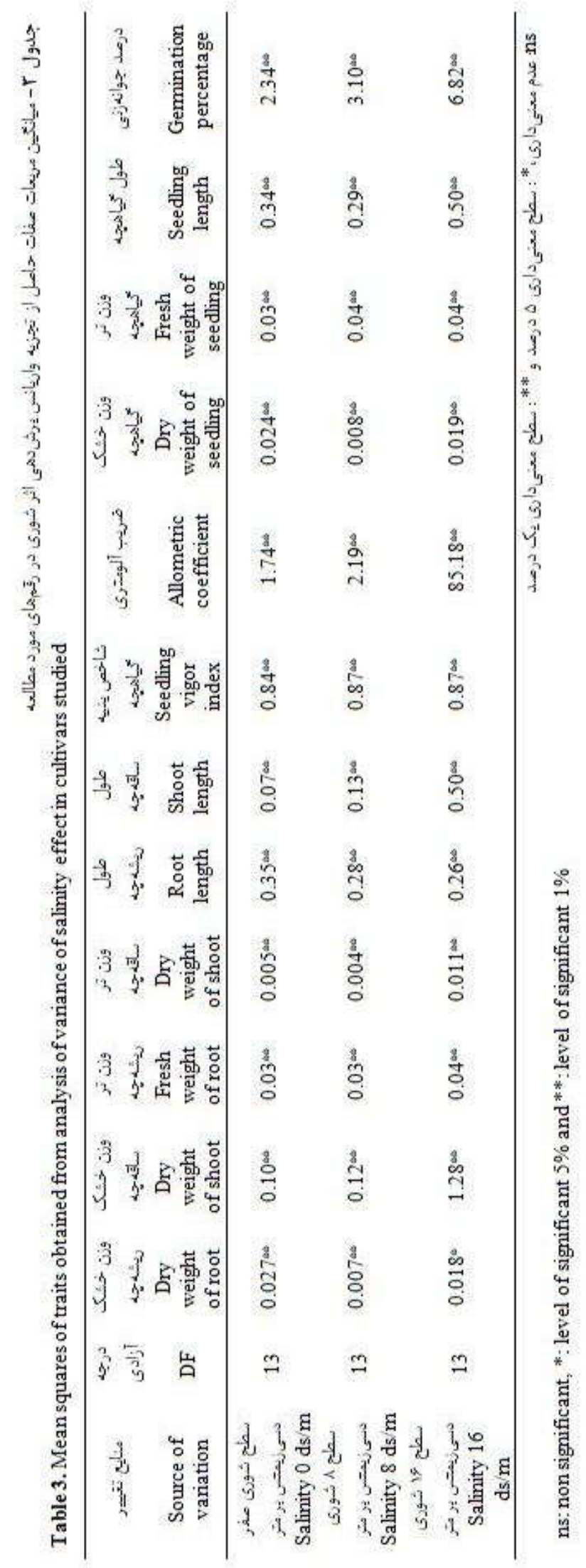




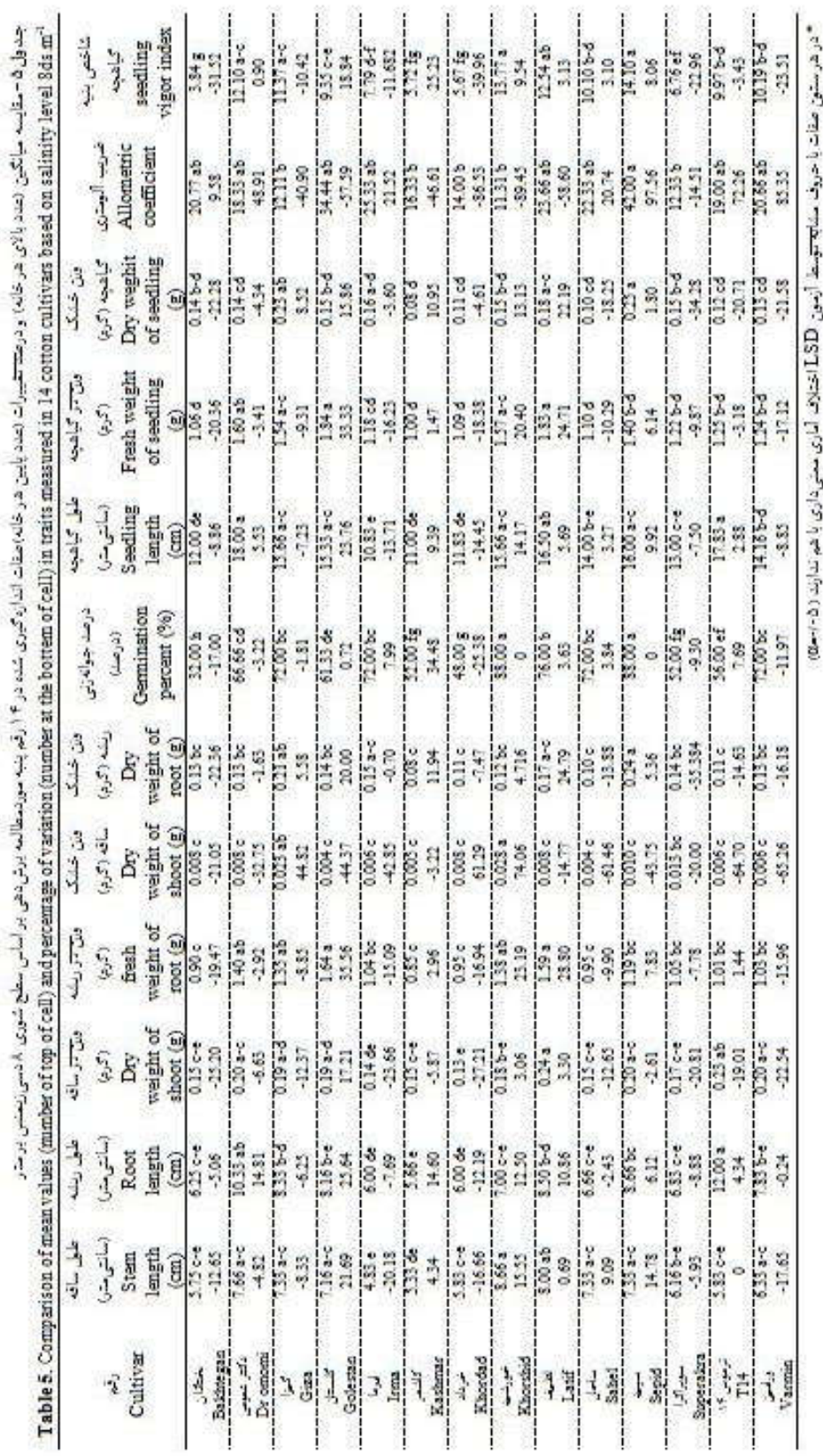




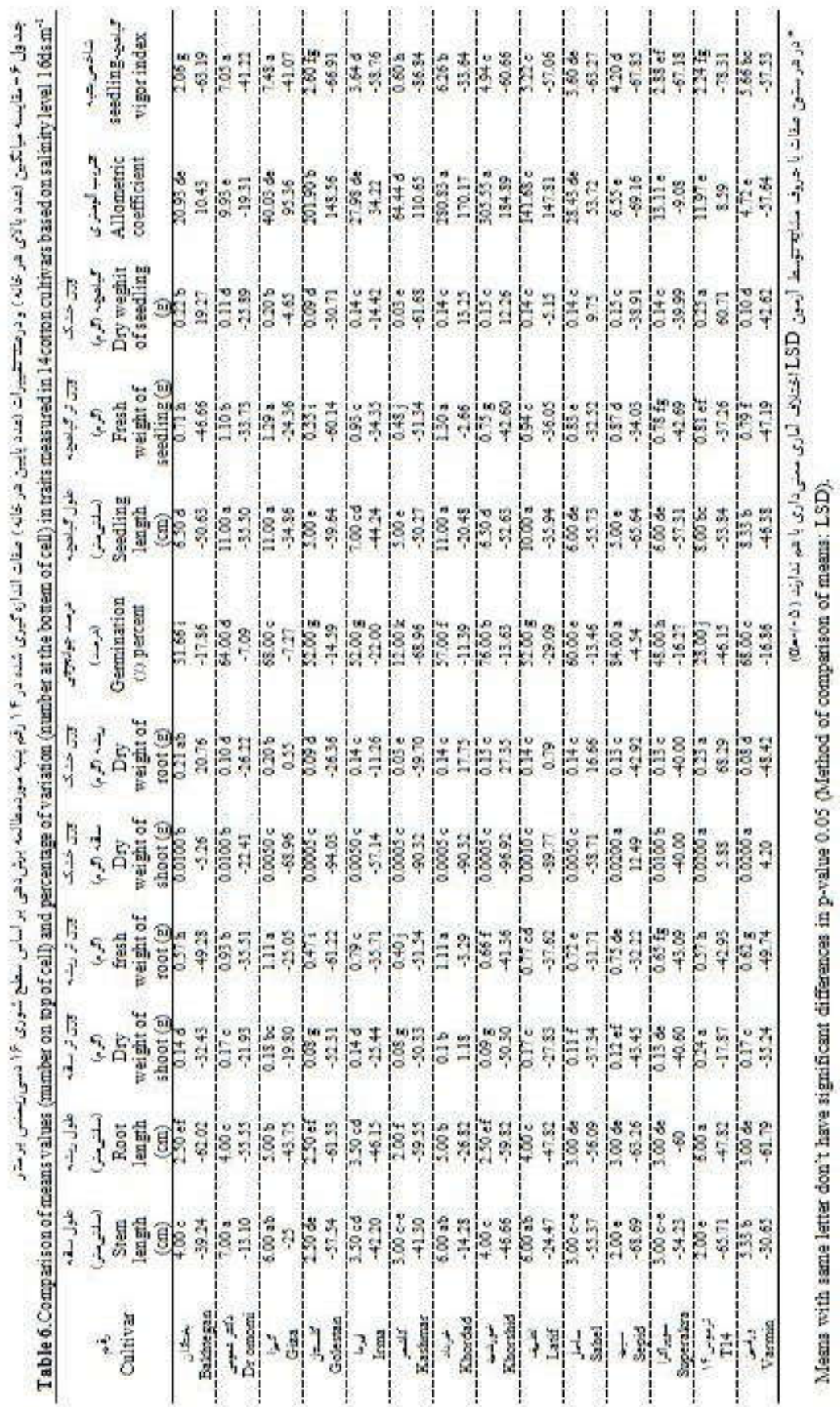




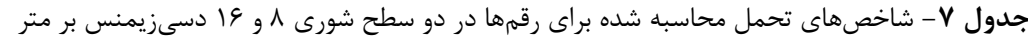

Table 7. Tolerance indices for cultivars at two levels of salinity of 8 and $16 \mathrm{ds} . \mathrm{m}^{-1}$

\begin{tabular}{|c|c|c|c|c|c|c|c|c|c|}
\hline \multirow[t]{2}{*}{ Cultivars } & \multirow{2}{*}{ رقم } & \multicolumn{4}{|c|}{ 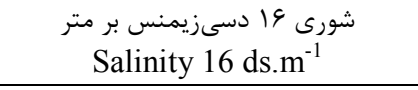 } & \multicolumn{4}{|c|}{ شورى ^ دسىزيمنس بر متر } \\
\hline & & STI & SSI & Ys & Yp & STI & SSI & Ys & $Y p$ \\
\hline Varmin & ورامين & 1.10 & 2.92 & 0.1 & 0.24 & 4.08 & 1.46 & 0.17 & 0.24 \\
\hline $\begin{array}{c}\text { Thermus } \\
14\end{array}$ & ترموس f| & 1.38 & -5.42 & 0.22 & 0.12 & 1.68 & -0.83 & 0.14 & 0.12 \\
\hline Kashmar & كاشمر & 0.14 & 3.48 & 0.03 & 0.1 & 1.25 & -1.25 & 0.12 & 0.1 \\
\hline Golestan & كلستان & 0.66 & 2.17 & 0.09 & 0.16 & 3.28 & -1.41 & 0.20 & 0.16 \\
\hline Bakhtegan & بختگان & 1.72 & -1.47 & 0.22 & 0.11 & 1.54 & -1.36 & 0.14 & 0.11 \\
\hline Khordad & خرداد & 0.90 & -0.02 & 0.14 & 0.14 & 1.33 & 1.61 & 0.09 & 0.14 \\
\hline Khorshid & خورشيد & 0.69 & -2.53 & 0.15 & 0.1 & 1.45 & -2.25 & 0.14 & 0.1 \\
\hline Dr omomi & دكتر & 0.71 & 1.07 & 0.11 & 0.14 & 2.45 & -1.25 & 0.17 & 0.14 \\
\hline Latif & لطيف & 0.97 & 0.30 & 0.14 & 0.15 & 3.15 & -2.00 & 0.21 & 0.15 \\
\hline sahel & ساحل & 0.73 & -1.59 & 0.14 & 0.11 & 1.37 & -0.68 & 0.12 & 0.11 \\
\hline Sepid & سييد & 0.76 & -1.82 & 0.15 & 0.17 & 2.55 & 0.59 & 0.15 & 0.17 \\
\hline Superakara & سويراكرا & 1.16 & 1.11 & 0.14 & 0.18 & 2.16 & 1.67 & 0.12 & 0.18 \\
\hline Giza & كيزا & 1.70 & -0.69 & 0.20 & 0.18 & 4.32 & -1.67 & 0.24 & 0.18 \\
\hline Irma & ايرما & 1.07 & 0.47 & 0.14 & 0.16 & 3.04 & -0.94 & 0.19 & 0.16 \\
\hline
\end{tabular}

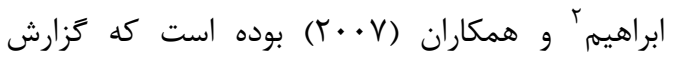
كردند شورى منجر به كاهش طول ساقه، سطح و مقدار

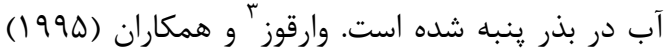

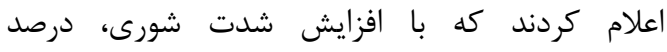
جوانهزنى، طول ريشه جهه و قسمت هوايى و بنيه گياهجه

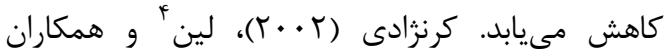
ا ( I99V) در كاهش درصد و سرعت جوانهزنى، طول ساقهجه، وزن

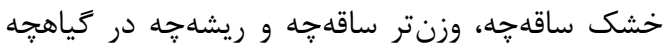
ينباه مؤثر دانستهاند. با افزايش شورى شاخص بنيه بذر نيز كاهش يافته

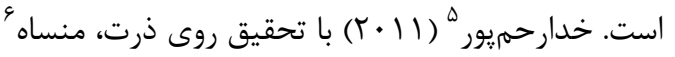

${ }^{2}$ Ibrahim

${ }^{3}$ Varghese

${ }^{4}$ Lin

${ }^{5}$ Khodarahmpour
بعد از برشدهى بر اساس سطوح شورى، ميانگين

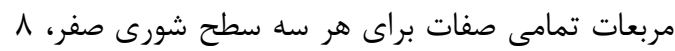
و 19 دسىزيمنس بر متر معنىدار شد. جدول س بماتى

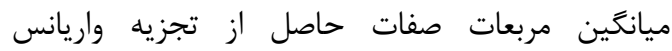
برشدهى اثر شورى در رقمهاى مورد مطالعه را نشان داده است.

در جدول \& مقايسه ميانگين صفات در سطح صفر دسىزيمنس بر متر، جدول ه مقايسه ميانخين و درصد تغييرات صفات در سطح ^ دسىزيمنس بر متر و جدول 9 مقايسه ميانگين و درصد تغييرات صفات در سطح شورى 19 دسىزيمنس بر متر را نشان داده است. بهطور كلى كاهش تمامى صفات با افزايش سطح شورى ديده شده است كه اين نتايج منطبق بر تحقيقات

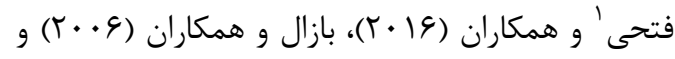

${ }^{1}$ Fathi 
جدول 9 ميزان همبستگى هر يك از شاخصها را با

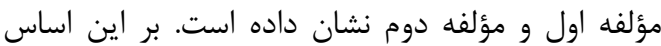

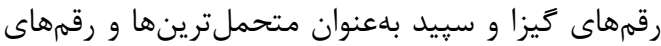

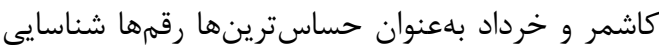
شدند. (شكل (1). بر اساس دستهبندى فرناندز (1999) رقمها در تجزيه خوشهبندى به روش وارد (شكل r) در جهار گروه متحمل، نيمه متحمل، نيمه حساس و و حساس قرار ترفتند.

در جدول • ا كروهها، ميزان تحمل، عملكرد تنش

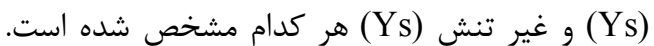
بر اساس اين گروهبندى رقمهاى گيزا و سيّيد داراى عملكرد بالا در دو محيط بودهاند. (دسته متحمل)،

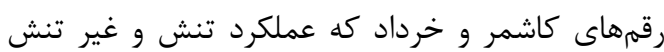
يايينى دارند (دسته حساس)، رقم سويراكرا كه داراى عملكرد بالايى در محيط غير تنش و عملكرد يايين در محيط تنش هستند (دسته نيمه متحمل) و رقمهاى

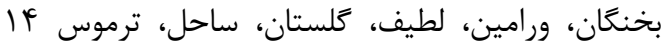

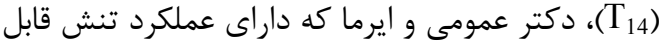
قبولى هستند بلعنوان دسته نيمه حساس دستهبندى

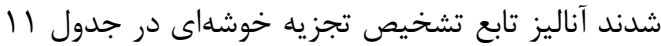

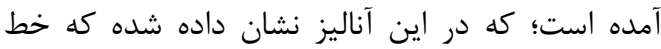

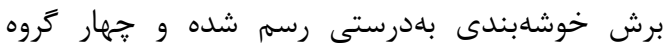
معنى دار شدهاند.

جدول 1 - مقادير ويزّه، درصد واريانس و سهم تجمعى شاخصهاى

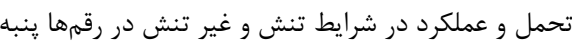

Table 8. eigenvalues, vaiance and cumulative Ys and $\mathrm{Yp}$ indices in cotton cultivars

\begin{tabular}{|c|c|c|}
\hline \multirow{2}{*}{$\begin{array}{c}\text { مورد } \\
\text { Function }\end{array}$} & \multicolumn{2}{|c|}{$\begin{array}{c}\text { محور مؤلفههاى اصلى } \\
\text { Principle componenet axis }\end{array}$} \\
\hline & PC1 مؤلفه اول PC1 & PC2 مؤلفه دوم PC2 \\
\hline $\begin{array}{c}\text { مقادير ويزه } \\
\text { Eigenvalue }\end{array}$ & 2.88 & 1.09 \\
\hline درصد واريانس & 72.19 & 27.37 \\
\hline $\begin{array}{c}\text { درصد واريانس } \\
\text { \%Cumulative }\end{array}$ & 72.19 & 99.56 \\
\hline
\end{tabular}

منساه' و همكاران (צ. • ب) با تحقيق روى بادامزمينى و

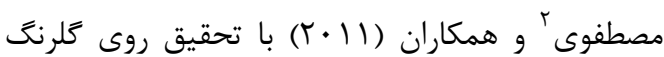
نشان دادند كه بنيه بذر طى تنش شورى كاهش مىيابد، در واقع شورى قادر است با غيرفعال كردن ندان برخى هورمونها و همجنين تأثير بر نفوذيذيرى غشا

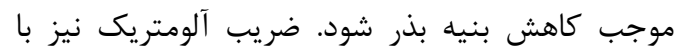
افزايش شورى روند كاهشى داشته است. علت اين امر يونهاى كلر و سديم حاصل از تنش شورى است كه باديا ايجاد يتانسيل اسمزى منفى، فرآيندهاى هيدروليزى بذر آنر

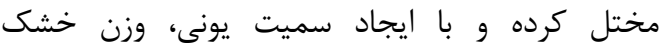
ريشهجه و ساقهجه را كاهش داده و با افزايش سطوح شورى روندى كاهشى به ضريب آلومتريك مى ربخشد.

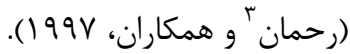

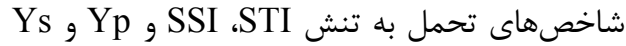

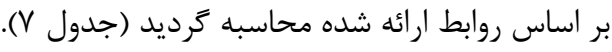

تجزيه خوشهاى در سطح شورى ^ دسىزيمنس بر

بامنظور تعيين متحملترين رقمها تجزيه جند

متغيره مؤلفههاى اصلى بر مبناى شاخصهاى تحمل SSI STI

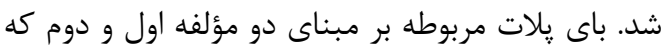

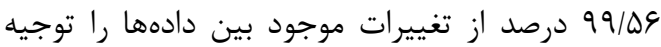
مىكردند، رسم كرديد (شكل (). در اين مطالعه مؤلفه

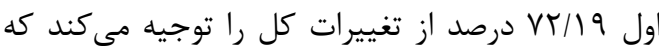
داراى همبستگى بالا و منفى با شاخص تحمل به تنش بوده است. مؤلفه دوم TV/TV دTI)

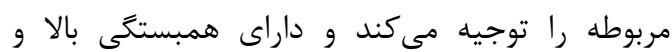
مثبتى با شاخص حساسيت به تنش (SSI) بوده است

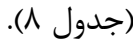
بر اساس همبستگى شاخصهاى STI و SSI با مؤلفه

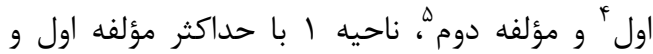
حداكثر مؤلفه دوم، ناحيه حساسيت و ناحيه ب با حداقل مؤلفه اول و حداقل مؤلفه دوم، ناحيه تحمل بوده است.

\footnotetext{
${ }^{1}$ Mensuh

${ }^{2}$ Mostafavi

${ }^{3}$ Rehman

${ }^{4} \mathrm{PC} 1$ (principal component 1)

${ }^{5}$ PC2 (principal component 2)
} 
جدول •1- تروهبندى رقمها بر اساس دستهبندى فرناندز، به همراه

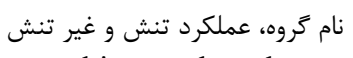

Table 10. Clustering cultivars based on Fernandez classification, along with the name of the group, Ys and Yp

\begin{tabular}{|c|c|c|c|}
\hline $\begin{array}{c}\text { گرووها } \\
\text { Groups }\end{array}$ & ميزان تحمل & عملكرد غير & عملكرد تنش \\
\hline 1 & $\begin{array}{c}\text { نيمه حساس } \\
\text { Semi- } \\
\text { sensetive }\end{array}$ & 0.16 & 0.13 \\
\hline 2 & $\begin{array}{c}\text { متحمل } \\
\text { Tolerant }\end{array}$ & 0.24 & 0.23 \\
\hline 3 & $\begin{array}{c}\text { حساس } \\
\text { Senetive }\end{array}$ & 0.10 & 0.09 \\
\hline 4 & $\begin{array}{c}\text { نيمه متحمل } \\
\text { Semi- } \\
\text { tolernat }\end{array}$ & 0.23 & 0.15 \\
\hline
\end{tabular}

جدول 9- تجزيه به مؤلفههاى اصلى براى عملكرد تنش و غير

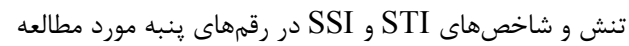
Table 9. Principal components for Ys and Yp and STI and SSI indices in cotton cultivars

\begin{tabular}{|c|c|c|}
\hline \multirow{2}{*}{$\begin{array}{l}\text { شاخص } \\
\text { Index }\end{array}$} & & \\
\hline & PC1 مؤلفه اول PC1 & PC2 مؤلفه دوم PC2 \\
\hline$Y p$ & -0.55 & 0.29 \\
\hline Ys & -0.58 & -0.14 \\
\hline SSI & 0.08 & 0.94 \\
\hline STI & -0.58 & -0.001 \\
\hline
\end{tabular}

$$
\text { جدول ll- آزمون تابع تشخيص براى تجزيه خوشهاى در شكل ا با استفاده از لامبداى ويلكس }
$$

\begin{tabular}{|c|c|c|c|c|}
\hline $\begin{array}{l}\text { Sig. } \\
\text { Sig }\end{array}$ & $\begin{array}{c}\text { درجه آزادى } \\
\text { df }\end{array}$ & $\begin{array}{c}\text { كاى اسكوئر } \\
\text { Chi-square }\end{array}$ & $\begin{array}{c}\text { لامبداى ويلكس } \\
\text { Wilks' Lambda }\end{array}$ & $\begin{array}{l}\text { آزمون توابع } \\
\text { Test of Function } \\
\text { (s) }\end{array}$ \\
\hline 0.0000 & 12 & 63.82 & 0.0008 & 1 \\
\hline 0.0000 & 6 & 36.70 & 0.016 & 2 \\
\hline 0.0017 & 2 & 12.70 & 0.243 & 3 \\
\hline
\end{tabular}

Table 11. Discriminant function analysis using Wilks' Lambda for cotton under salt stress for Figure 1

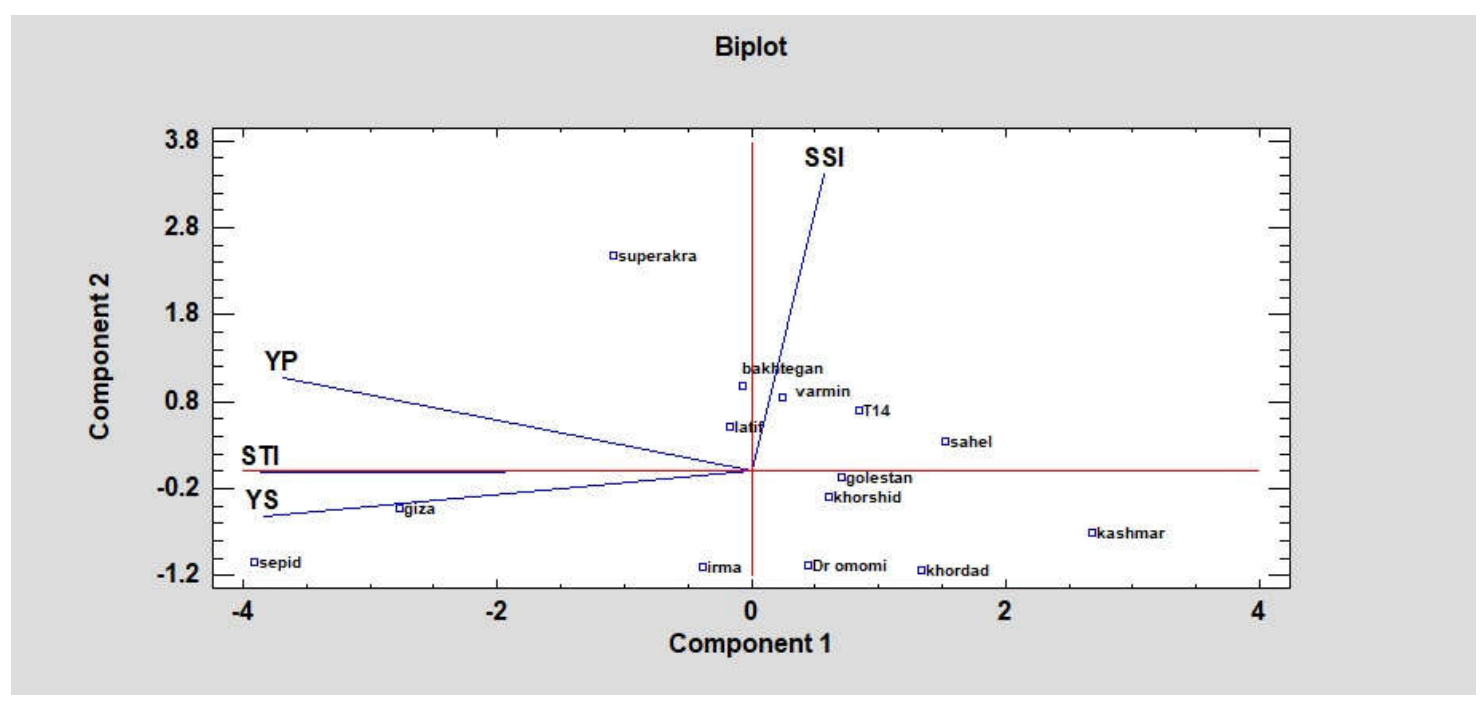

شكل ا- نمودار باى يلات رقمهاى مورد مطالعه در سطح شورى ^ دسىزيمنس بر متر بر اساس شاخص حساسيت به تنش (SSI)، (STI)، شاخص تحمل

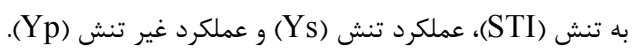

Figure 1. Biplot graph of cotton cultivars at salinity level $8 \mathrm{ds} \cdot \mathrm{m}^{-1}$ based on tolerance (STI) and susceptible (SSI) indices, the first and second principal component 


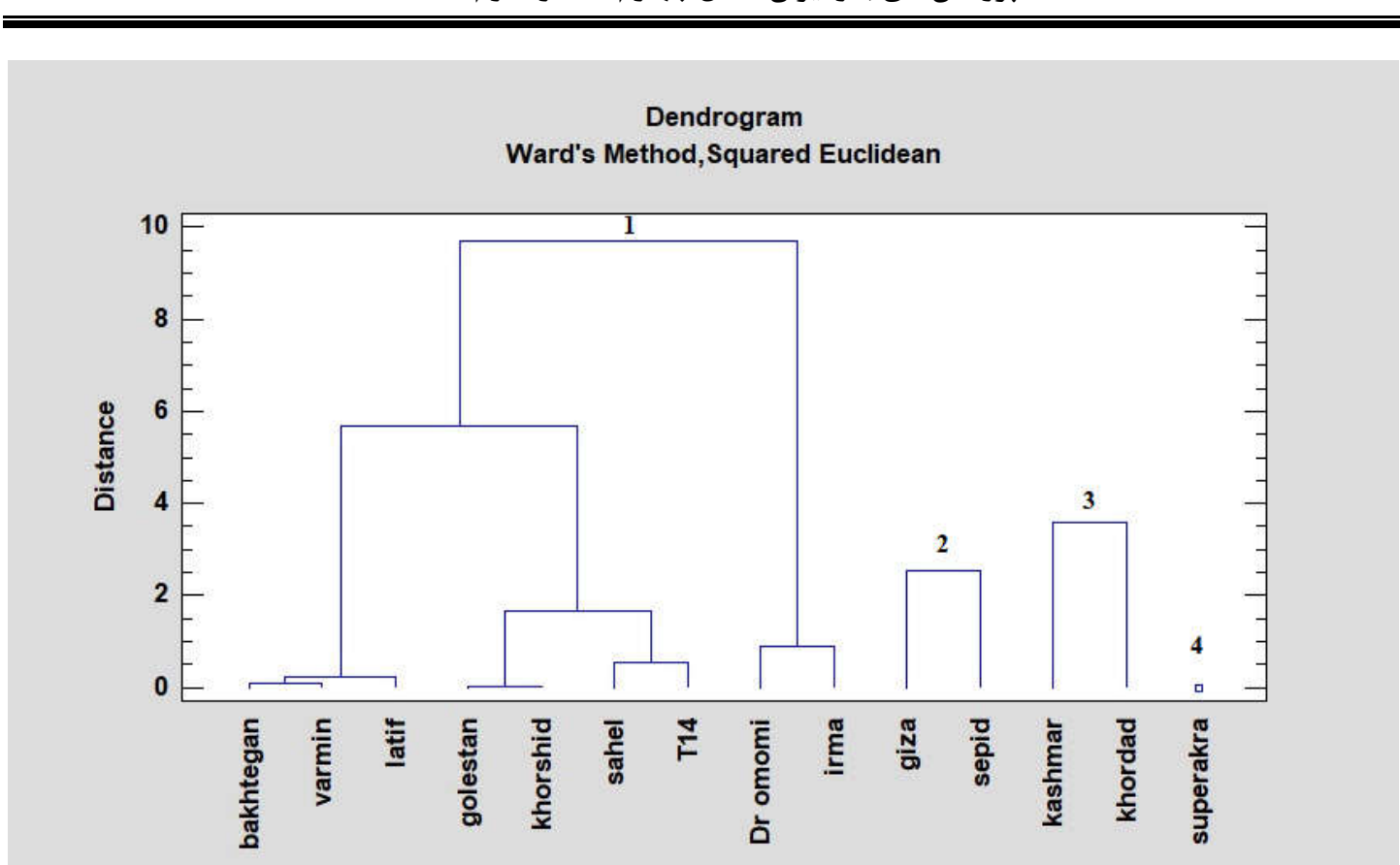

شكل r- دندروكرام رقمها مورد مطالعه در سطح شورى ^ دسىزيمنس بر متر بر اساس شاخص حساسيت به تنش (SSI)، (STI)، شاخص تحمل به

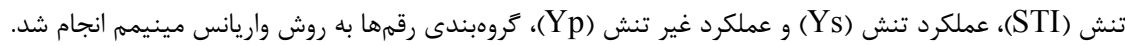

Figure 2. Dendrogram of cotton cultivars studied at salinity level $8 \mathrm{ds} . \mathrm{m}^{-1}$ based on tolerance (STI) and susceptible (SSI) indices, Ys and Yp using WARD method

سويراكرا بهعنوان متحملترينها و رقم كاشمر بهعنوان

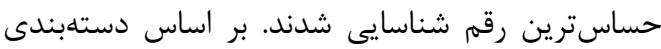

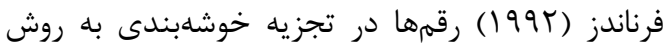

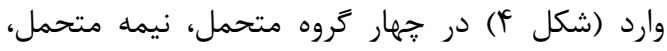

$$
\text { نيمه حساس و حساس قرار كرفتند. }
$$

در جدول f| أ كروهها، ميزان تحمل، عملكرد تنش

و غير تنش (Ys) هر كدام مشخص شده است. بر (Ys)

اساس اين كروهبندى رقمهاى كيزا، سييد و سوريراكرا داراى عملكرد بالا در دو محيط بودهاند. (دسته متحمل)،

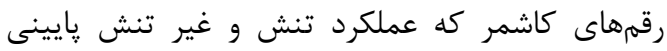
دارند (دسته حساس)، رقم بختكان، دكتر عمومى، ترموس \&l (T14)، كلستان و ورامين كه داراى عملكرد بالايى در محيط غير تنش و عملكرد بإيين در محيط تنش هستند (دسته نيمه متحمل) و رقمهاى خرئ خرداد، ساحل و خورشيد كه داراى عملكرد تنش قابل قبولى

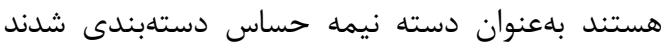
آناليز تابع تشخيص تجزيه خوشهاى در جدول هان آ آمده

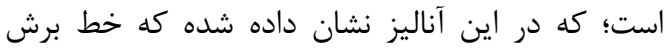

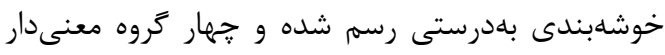

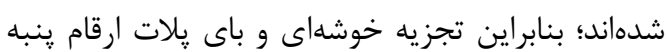

تجزيه خوشهاى در سطح شورى 1 دسىزيمنس بر متر بلمنظور تعيين متحملترين رقمها تجزيه جند متغيره مؤلفههاى اصلى بر مبناى شاخصهاى تحمل

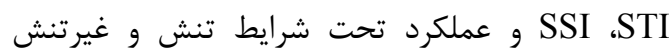
انجام شد. باى پِلات مربوطه بر مبناى دو مؤلفه اول و و

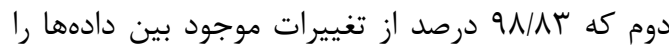
توجيه مى كردند، رسم كرديد (شكل ؟ّ). در اين مطالعه

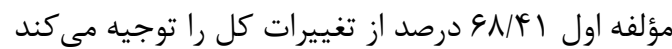
كه داراى همبستگى بالا و منفى با شاخص تحمل به إنه

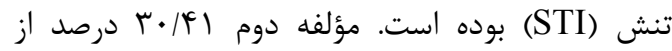
تغييرات مربوطه را توجيه مى كند و داراى همبستكى بالا و مثبتى با شاخص حساسيت به تنش (SSI) بوده است

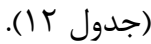
بر اساس همبستكى شاخصها با مؤلفه اول و مؤلفه

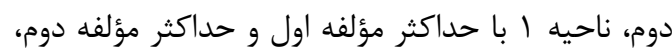
ناحيه تحمل و ناحيه ب با حداقل مؤلفه اول و حداقل مؤلفه دوم، ناحيه حساسيت است. جدول باحيه با ما ميزان همبستگى هر يك از شاخصها را با مؤلفه اول و مؤلفه

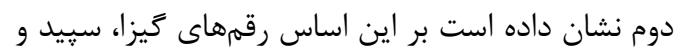


جدول سا - تجزيه به مؤلفههاى اصلى براى عملكرد تنش و غير تنش

و شاخص هاى STI و SSI در رقمهاى ينبه مورد مطالعه

Table 13. Principal compoenets for Ys and Yp and STI and SSI indices in cotton cultivars

\begin{tabular}{|c|c|c|c|}
\hline مؤلفه اول PC1 & \multicolumn{3}{|c|}{ مؤلفه اول PC1 } \\
\hline $\bar{Y}$ & & & 0.48 \\
\hline Y & & & -0.24 \\
\hline $\mathrm{S}$ & & & 0.19 \\
\hline S & & & 0.81 \\
\hline \multicolumn{4}{|c|}{ 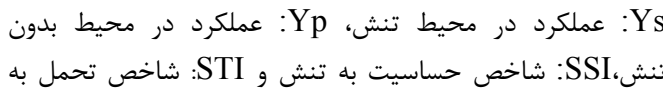 } \\
\hline \multirow{2}{*}{\multicolumn{4}{|c|}{ 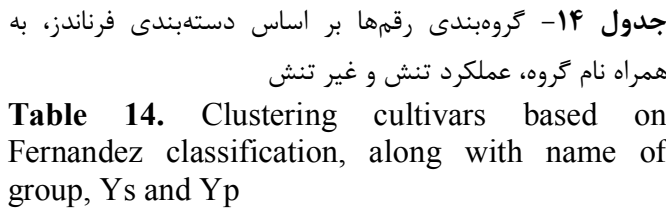 }} \\
\hline & & & \\
\hline كروهاها & كروهاها & كروهها & تروهها \\
\hline Groups & Groups & Groups & Groups \\
\hline 1 & نيمه متحمل & 0.16 & 0.11 \\
\hline 2 & متحمل & 0.23 & 0.16 \\
\hline 3 & $\begin{array}{c}\text { حساس } \\
\text { Senetive }\end{array}$ & 0.08 & 0.03 \\
\hline 4 & $\begin{array}{c}\text { نيمه حساس } \\
\text { Semi- } \\
\text { sensetive }\end{array}$ & 0.14 & 0.13 \\
\hline
\end{tabular}

جدول ها - آزمون تابع تشخيص براى تجزيه خوشهاى در شكل ا با

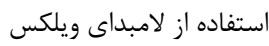

Table 15. Discriminant function analysis using Wilks' Lambda for cotton under salt stress for Figure 1

\begin{tabular}{|c|c|c|c|c|}
\hline $\begin{array}{l}\text { آزمون توابع } \\
\text { Tet of } \\
\text { Function } \\
\text { (s) }\end{array}$ & $\begin{array}{c}\text { آزمون توابع } \\
\text { Test of } \\
\text { Function } \\
\text { (s) }\end{array}$ & $\begin{array}{l}\text { آزمون توابع } \\
\text { Test of } \\
\text { Function } \\
\text { (s) }\end{array}$ & $\begin{array}{l}\text { آزمون توابع } \\
\text { Test of } \\
\text { Function } \\
\text { (s) }\end{array}$ & $\begin{array}{c}\text { آزمون توابع } \\
\text { Test of } \\
\text { Function } \\
\text { (s) }\end{array}$ \\
\hline 1 & 0.0005 & 68.34 & 12 & 0.0000 \\
\hline 2 & 0.013 & 38.88 & 6 & 0.0000 \\
\hline 3 & 0.262 & 12.04 & 2 & 0.0024 \\
\hline
\end{tabular}

روشى مناسب براى دستهبندى اين ارقام براى تنش

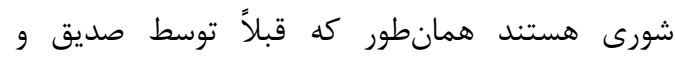

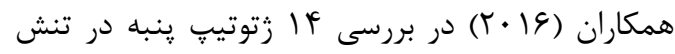
خشكى تأييد كردند كه شاخصهاى حساسيت به تنش (SSI)

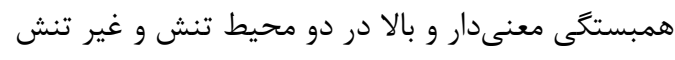

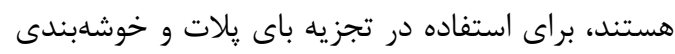
و انتخاب رقمهاى متحمل و حساس مناسب هستند. نتيجه گيرى

دستهبندى و باى يلات رقمها بر اساس اين شاخصها

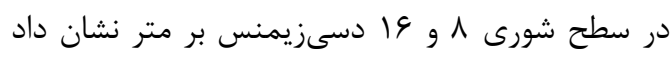

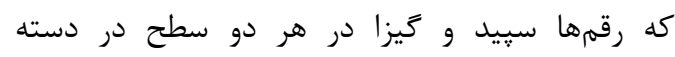
متحملها و رقمها كاشمر در هر دو سطح در زرئ دروه حساسها در مرحله جوانهزنى بر اساس شاخصهاى رفهاى و STI محققين است. بهطور كلى دستهبندى رقمها و باى پيلات براى شناسايى رقمهاى متحمل گپنبه از حساس كاربرد قابل توجهى دارد.

\section{سياسگزן ارى}

بدينوسيله از يزوهشكده زنتيك و زيستفناورى

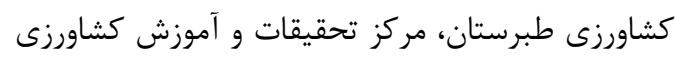

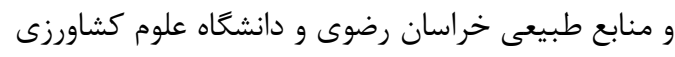

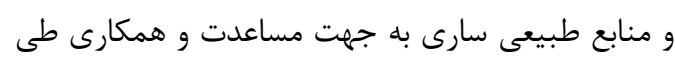

$$
\text { اجراى اين يروهش قدردانى مىشود. }
$$

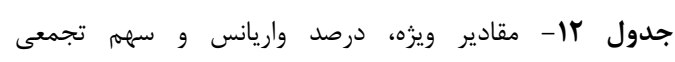
شاخصهاى تحمل و عملكرد در شرايط تنش و غير تنش در رقمها

Table 12. Eigenvalues, vaiance and cumulative percentage, Ys and Yp indices in cotton cultivars

\begin{tabular}{|c|c|c|}
\hline $\begin{array}{c}\text { مورد } \\
\text { Function }\end{array}$ & مؤلفه اول PC1 & مؤلفه دوم PC2 \\
\hline $\begin{array}{c}\text { مقادير ويزء } \\
\text { Eigenvalue }\end{array}$ & 2.42 & 1.50 \\
\hline $\begin{array}{c}\text { درصد واريانس جزء } \\
\text { Variance\% }\end{array}$ & 68.41 & 30.41 \\
\hline درصد واريانس تجمعى & 68.41 & 98.83 \\
\hline
\end{tabular}




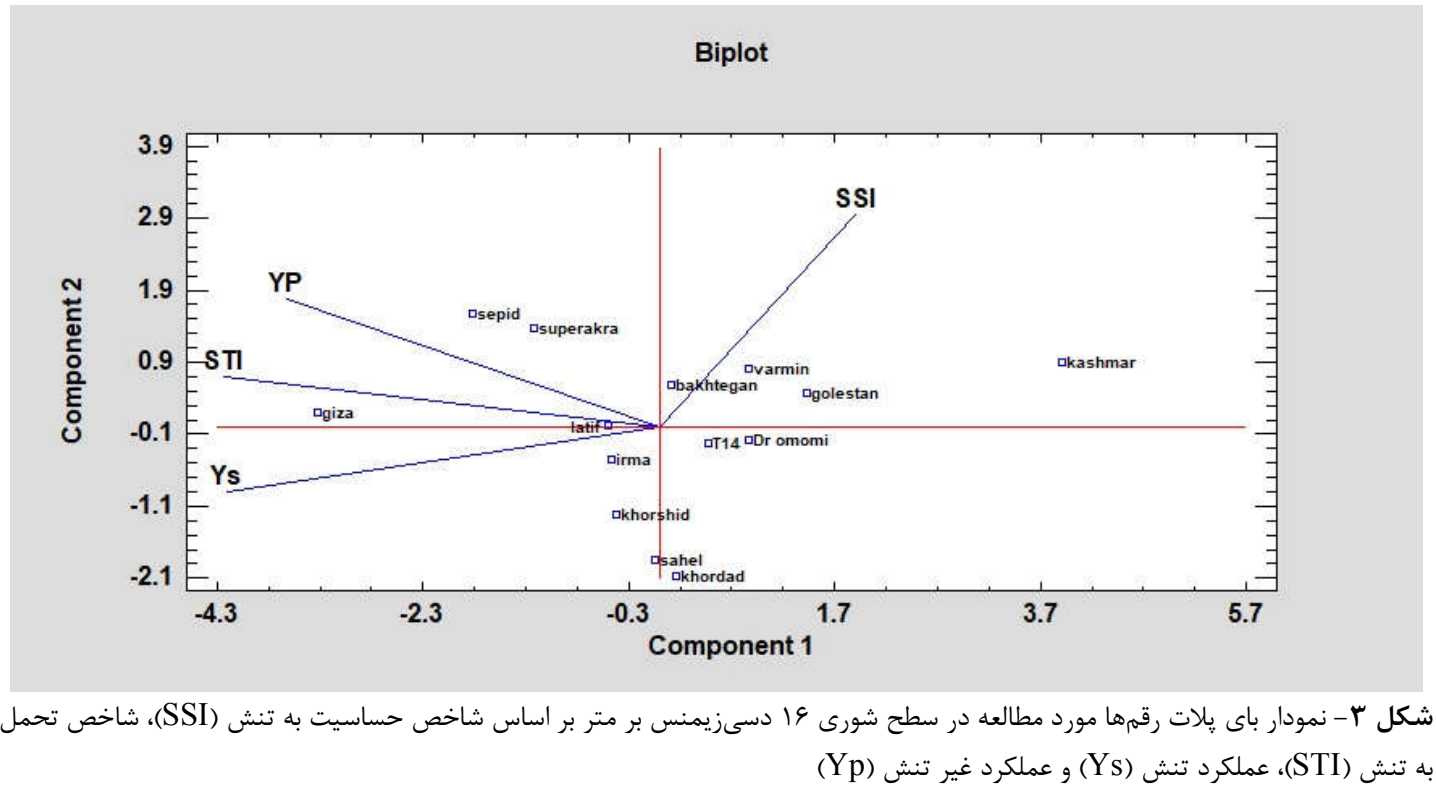

Figure 3. Biplot graph of cotton cultivars and tolerance (STI) and susceptible (SSI) indices based on the first and second principal component at salinity level of $16 \mathrm{ds} . \mathrm{m}^{-1}$

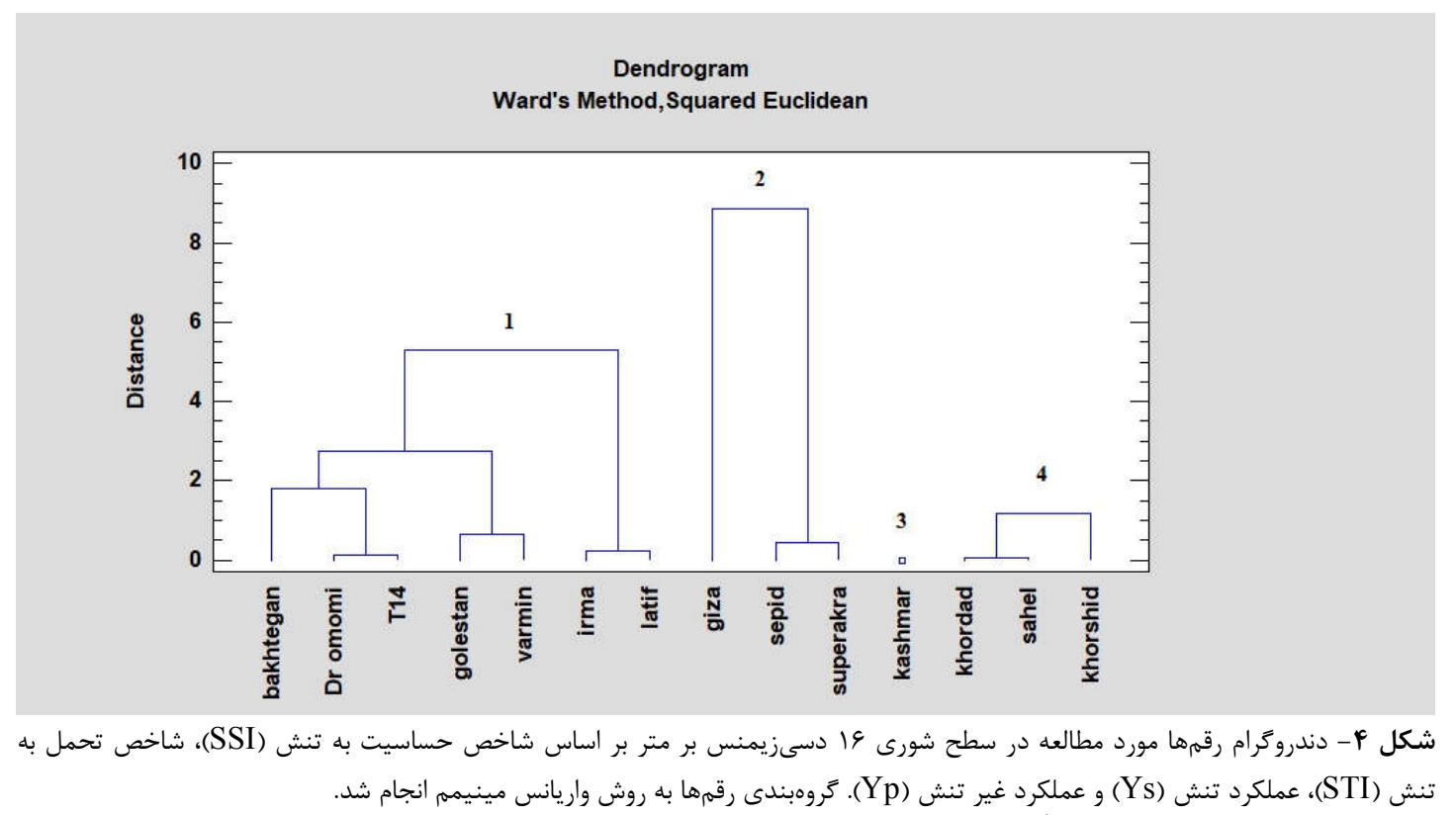

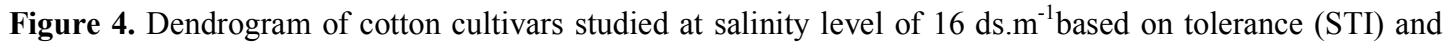
susceptible (SSI) indices, Ys and Yp, using WARD method

منابع

Abdul-Baki, A., and Anderson, J.D. 1973. Vigor determination in Soybean seed by multiple criteria. Crop Science, 13(6): 630-633.

https://doi.org/10.2135/cropsci1973.0011183X001300060013x

Abul-Naas, A.A., and Omran, M.S. 1974. Salt tolerance of seventeen cotton cultivars during germination and early seedling development. ZAcker Pflanzenbau, 140: 229-236. 
Akbari, L., Cheghamirza, K., and Farshadfar, E. 2017. In vitro evaluation of drought tolerance in durum wheat genotypes (Triticum durum L.). Journal of plant research (Iranian Journal of Biology), 29(2): 273-285. [In Persian with English Summary].

Alishah, O., and Ahmadikhah, A. 2009. The effects of drought stress on improved cotton varieties in Golestan province of Iran. International Journal of Plant Production, 3(1): 1-10.

Basal, H. 2010. Responsive of cotton (Gossypium hirsutum L.) genotypes to salt stress. Pakistan Journal of Botany, 42(1): 505-511.

Basal, H., Demiral, M.A., and Canavar, O. 2006. Shoot biomass production of converted race stocks of upland cotton (Gossypium hirsutum L.) exposed to salt stress. Asian Journal of Plant Science, 5(2): 238-242. https://doi.org/10.3923/ajps.2006.238.242

Fathi Sadabadi, M., Ranjbar, G.A., Zangi, M.R., Kazemi Tabar, S.K., and Najafi Zarini, H. 2016. 2nd national congress on the development of agricultural science and natural resources. Farhangian university-Golestan province. [In Persian].

Fernandez, G.C.J. 1992. Effective selection criteria for assessing stress tolerance. In: Kuo, C.G. (ed.). Proceedings of the International Symposium on Adaptation of Vegetables and Other Food Crops in Temperature and Water Stress, Publication, Tainan, Taiwan.

Fische, R.A., and Maurer, R. 1978. Drought resistance in spring wheat cultivars: I. Grain yield responses. Australian Journal Agricultural Research, 29(5): 897-912. https://doi.org/10.1071/AR9780897

Ibrahim, M.J., Akhtar, M., Younis, M.A., Riaz, Anwar-ul-Haq, M., and Tahir, M. 2007. Selection of cotton (Gossypium hirsutum L.) genotypes against $\mathrm{NaCl}$ stress. Soil and Environment, 26(1): $59-63$.

International Seed Testing Association. 1985. International rules for seed testing. Rules 1985. Seed Science and Technology, 13(2): 299-513.

Kamrava, S., Babaeian Jelodar, N.A., and Bagheri, N.A. 2016. Evaluation of some soybean genotypes (Glycine max) under salt stress. Journal of Crop Breeding 8(18): 57-63. [In Persian with English Summary]. https://doi.org/10.29252/jcb.8.18.57

Khan, A.N., Qureshi, R.H., Ahmad, N., and Rashid, A. 1995. Response of cotton cultivars to salinity in various growth development stages. Sarhad Journal of Agriculture, 11: 729-731.

Khodarahmpour, Z. 2011. Screening maize (Zea mays L.) hybrids for salt stress tolerance at germination stage. African Journal of Biotechnology, 10(71): 15959-15965. https://doi.org/10.5897/AJB11.2493

Kor Nejadi, A. 2002. Selection of cotton cultivars for salinity tolerance at germination and seedling stage. M.Sc. Thesis. The Gorgan University of Agriculture Science and Natural Resources 106p. [In Persian].

Lin, H., Salus, S., and Schumaker, S. 1997. Salt sensitivity and the activity of the H+- At pass in cotton seedling, Crop Science, 37: 190-197. https://doi.org/10.2135/cropsci1997.0011183X003700010032x

Maas, E.V., and Hoffmann, G.J. 1977. Crop salt tolerance current assessment. Journal Irrigation Drainage Divid, ASCE, 103: 115-134.

Maguire, J.D. 1962. Speed of germination-aid in selection and evaluation for seedling emergence and vigour. Crop Science, 2(2): 176-177. https://doi.org/10.2135/cropsci1962.0011183X000200020033x

Marashi, S.S., Hajilou, J., Tabatabaei, S.J., Nahandi F.Z., and Toorchi, M. 2017. Screening date palm cultivars for salinity tolerance using physiological indices. Pakistan Journal of Botany, 49(2): 413-419. 
Mashhadi, F. 2013. Identification of quantitative and qualitative characteristics effective on cotton yield under salinity stress. M.Sc. Thesis. Tehran University of College of Abouraihan 75p. [In Persian].

Mensuh, J.K., Akomeah, P.A., and Ikhajiagbe, B. 2006. Ekpekurede effects of salinity on germination, growth and yield of five groundnut genotypes. African Journal of Biotechnology, 5(20): 1973-1979.

Mohammadzadeh, M. Norozi, M. Peighambari, S.A., and Nabipoor, A. 2008. Evaluating the response of rice genotypes to salinity stress in germination stage. Journal of Crop Breeding, 1(1): 10-21. [In Persian with English Summary].

Mohammadzadeh, M., Peighambari, S.A., Nabipoor, A.R., and Norouzi, M. 2009. Evaluation of the using of rice genotypes response to salinity stress at seedling stage in hydroponic culture. Journal of Crop Breeding, 1(2): 85-95. [In Persian with English Summary].

Mostafavi, K. 2011. An evaluation of safflower genotypes (Carthamus tinctorius L.), seed germination and seedling characters in salt stress conditions. African Journal of Agricultural Research, 7: 1667-1672.

Motamedi, M., Khodarahmpour, Z., Naseri Rad, H. 2011. Study of physiologic tolerance of safflower (Carthamus tinctorius L.) genotypes on salinity stress in germination stage and seedling growth. Journal of Crop Breeding, 3(8): 81-92. [In Persian with English Summary].

Munns, R., and Termaat, A. 1986. Whole-plant responses to salinity. Australian Journal of Plant Physiology, 13: 143-160. https://doi.org/10.1071/PP9860143

Rehman, S., Harris, P.J.C., Bourne, W.F., and Wikin, J. 1997. The effect of sodium chloride on germination and the potassium and calcium contents of Acacia seeds. Seed Science and Technology, 25(1): 45-57.

Rezaee, S., Ramazani Moghaddam, M.R., and Bazrgar, A.B. 2015. Cottonseed germination as affected by salinity and priming. Indian Journal of Fundamental and Applied Life Sciences, 5(1): 312-318.

Sedigh S., Zabet M., Ghaderi M.Gh., and Samadzadeh A.R., 2015. Determination of the Suitable indices for drought tolerance in cotton genotypes, Iranian Journal of Cotton Researches, 3(2): 41-53. [In Persian with English Summary].

Sedigh, S., Zabet, M., Ghaderi, M.G. and Samadzadeh, A.R. 2016. Identification of superior varieties of Cotton (Gossypium hirsutum L.) under drought stress and normal conditions using GGEBiplot and GTBiplotmethod in Birjand. Journal of Crop Breeding, 8(19): 134-144. [In Persian with English Summary].

Shirazi, E., Fazeli-nasab, B., Ramshin, H.A., Fazel-Najaf-Abadi, M., and Izadi-darbandi, A. 2016. Evaluation of drought tolerance in wheat genotypes under drought stress at germination stage. Journal of Crop Breeding, 8(20): 207-219. [In Persian with English Summary].

Varghese, S., Patel, K.V., Gohil, M.D., Bhatt, P.H., and Patel, G. 1995. Response of OT 11 leant cotton (Gossypium herbaceum) to salinity at germination stage. Indian Journal of Agriculture Science, 65: 823-825.

Zangi, M.R. 2005. Correlation between drought resistance indices and cotton yield in stress and non-stress conditions. Asian Journal of Plant Sciences, 4(2): 106-108. https://doi.org/10.3923/ajps.2005.106.108 


\title{
Evaluation of Salinity Tolerance in allotetraploid Cotton (Gossypium sp.) Genotypes, Using Multivariate Statistical Methods and Stress Tolerance Indices at Germination Stage
}

\author{
Nafiseh Taghizadeh ${ }^{1}$, Gholam Ali Ranjbar ${ }^{1, *}$, Ghorban Ali Nematzadeh², Mohammad Reza \\ Ramazani Moghaddam ${ }^{3}$ \\ ${ }^{I}$ Ph. D. Student, Department of Plant Breeding and Biotechnology, Sari Agricultural Sciences and \\ Natural Resources University (SANRU), Sari, Iran \\ ${ }^{2}$ Associate Professor and Professor, Genetics and Agricultural Biotechnology Institute of \\ Tabarestan (GABIT), Sari, Iran \\ ${ }^{3}$ Assistant Professor, Horticultural Crops Science Research Department, Khorasan Razavi \\ Agricultural and Natural Resources Research and Education Center AREEO, Mashhad, Iran \\ "Corresponding author, E-mail address: ali.ranjbar@gmail.com
}

(Received: 31.07.2017; Accepted: 28.01.2018)

\begin{abstract}
Salinity is one of the most important factors limiting agricultural production. Cotton, as an oilfiber plant, is one of the most important industrial plants and is sensitive to salinity, especially at germination and seedling stages. Therefore, in this study, 14 allotetraploid varieties of commercial and local cotton were selected. The study was carried out as factorial with a completely randomized design and three three replications, using the sandwich method. Germination tests were performed at three salinity levels of 0,8 and $16 \mathrm{ds} \cdot \mathrm{m}^{-1}$. Afterwards, root and shoot length, fresh and dry weight of root and shoot, germination percentage, allometric coefficient, seedling water percentage and seed vigor index were measured and stress tolerance indices were calculated based on yield (seedling dry weight) in stress and non-stress conditions. Given these indices, all cultivars were aalyzed at two levels of 8 and $16 \mathrm{ds} \cdot \mathrm{m}^{-1}$, using principal component analysis and biplot diagrams were drawn. Finally, the dendrogram classification of genotypes was plotted based on STI indices (stress tolerance index), SSI (stress susceptibility index), and the performance (dry weight plantlet) in stress and non-stress conditions. The result of variance analysis for genotype, salinity and salinity $\times$ genotype demonstrated that dry weight root, dry weight shoot, fresh weight root, stem length, vigor index seedling, allometric coefficient, dry weight seedling, and length seedling were significant in p-value 0.01 , and fresh weight shoot, length root were significant in p-value 0.05 . Clustering and the biplot of the genotypes based on STI and SSI indices at salinity levels of 8 and 16 ds. $\mathrm{m}^{-1}$ indicated that the Sepid and Giza genotypes were tolerant and that the Kashmar genotype was sensitive to salt levels at germination stage.
\end{abstract}

\section{Keywords: Biplot, Cotton, Germination, Salt, Principal components}

\section{Highlights:}

1. The reaction of the cotton cultivars studied was different to levels of salinity stress.

2. An increase in salt stress caused a significant reduction in the germination characteristics of cultivars of cotton studied.

3. Bi-plot analysis and clustering based on STI and SSI indices turned out to be a suitable method for clustering cotton cultivars.

DOI: $10.29252 /$ yujs.4.2.93 